\title{
Purification of polygalacturonases produced by Aspergillus niger using an aqueous two-phase system
}

\author{
Marília de H.C. Maciel ${ }^{\mathrm{a}, \mathrm{b}}$, Cristiane A. Ottoni ${ }^{\mathrm{b}}$, Polyanna N. Herculano ${ }^{\mathrm{c}}$, Tatiana S. Porto ${ }^{\mathrm{e}}$, \\ Ana L.F. Porto ${ }^{c}$, Cledir Santos ${ }^{b, d}$, Nelson Lima ${ }^{b}$, Keila A. Moreira ${ }^{e}$, Cristina Souza-Motta $^{a, *}$ \\ a Department of Mycology, Federal University of Pernambuco, Cidade Universitária, Recife, PE 50670-420, Brazil \\ ${ }^{\mathrm{b}}$ CEB-Centre of Biological Engineering, Micoteca da Universidade do Minho, University of Minho, Campus of Gualtar, 4710-057 Braga, Portugal \\ ' Department of Animal Morphology and Physiology, Federal Rural University of Pernambuco, Recife, PE 52171-900, Brazil \\ d Programa de Pós-Graduação em Agronomia Tropical, Faculdade de Ciências Agrárias, Universidade Federal do Amazonas, Manaus, AM, Brazil \\ e Academic Unit of Garanhuns, Federal Rural University of Pernambuco, Garanhuns, PE 55292-270, Brazil
}

\section{A R T I C L E I N F O}

\section{Article history:}

Received 16 May 2013

Received in revised form 10 March 2014

Accepted 19 March 2014

Available online 28 March 2014

\section{Keywords:}

Aspergillus niger

Partition

PEG/phosphate ATPS

Polygalacturonases

Purification factor

\begin{abstract}
A B S T R A C T
The partitioning and purification of polygalacturonases (PG) produced by Aspergillus niger URM 5162 were investigated in aqueous two-phase systems (ATPS), formed by polyethylene glycol and phosphate salts (PEG/phosphate). To evaluate the effect of the 4 independent variables - molar mass of polyethylene glycol (PEG) (400-8000 g/mol - $M_{\mathrm{PEG}}$ ), PEG concentration (12.5-17.5\%, w/w - $C_{\mathrm{PEG}}$ ), phosphate concentration (15-25\%, w/w, $\left.C_{\mathrm{PHOS}}\right)$ and $\mathrm{pH}(6.0-8.0)$ - on the 4 response variables: partition coefficient $(K)$, activity yield $(Y)$, purification factor $(\mathrm{PF})$ and selectivity $(S)$, a factorial design $\left(2^{4}\right)$ was used. The endopolygalacturonases (endo-PG) and exo-polygalacturonase (exo-PG) were preferentially partitioned in the top phase. For endo- and exo-PG, the highest values for the response variables $K(1.23$ and 2.40$), Y$ (74.04\% and $17.97 \%), P F(8.18$ and 1.98$)$ and $S$ (24.68 and 48.07), respectively, were obtained for a $C_{\mathrm{PEG}}$ of $12.5 \%(\mathrm{w} / \mathrm{w}), M_{\mathrm{PEG}}$ of $8000 \mathrm{~g} / \mathrm{mol}$, and $C_{\mathrm{PHOS}}$ of $25 \%(\mathrm{w} / \mathrm{w})$ at $\mathrm{pH}$ 6.0. These conditions were considered the most suitable for the purification of PG produced by A. niger URM 5162. Furthermore, the most important independent variables for endo- and exo-PG were $C_{\mathrm{PHOS}}$ and $M_{\mathrm{PEG}}$, respectively. All independent variables studied and their interactions significantly influenced the response variables. According to these results, the PEG/phosphate system is a useful cost-effective alternative for purification of PG produced by A. niger URM 5162.
\end{abstract}

(c) 2014 Elsevier B.V. All rights reserved.

\section{Introduction}

Pectinases, or pectinolytic enzymes, are a heterogeneous group of enzymes catalysing the degradation of the pectin component in the cell wall in plants. They are produced by different species of filamentous fungi, bacteria and yeasts [1,2]. Filamentous fungi are the most frequently used microorganisms in the enzyme industry because at least $90 \%$ are produced extracellularly [3-5], hence saving on costs from extraction of whole cells. Aspergillus niger is the most commonly used fungus in large-scale production of pectinolytic enzymes [6] and has been assigned the status of Generally Recognised As Safe (GRAS) by the United States Food and Drug Administration (FDA). In addition, the World Health Organisation (WHO) considers fungi as ideally exploitable for biotechnology [7].

\footnotetext{
* Corresponding author. Tel.: +55 81 21268948; fax: +55 8121268480.

E-mail addresses: smotta@ufpe.br, souzamotta@yahoo.com.br (C. Souza-Motta).
}

Worldwide interest in pectinolytic enzymes has increased particularly because of their efficacy in improving fruit juice quality and high industrial value [8]. Polygalacturonases (PG) are among the most extensively studied pectinolytic enzymes [9]. PG catalyse the hydrolytic cleavage of the polygalacturonic acid chain by the introduction of a water molecules across each oxygen bridge [10]. PG are classified as endo-polygalacturonases (endo-PG - E.C. 3.2.1.15) or exo-polygalacturonases (exo-PG - E.C. 3.2.1.67). EndoPG act randomly on the polygalacturonic acid molecule to release oligogalactorunic acid, whereas exo-PG act on terminal monomers of polygalacturonic acid to release monogalacturonic acid [11-13].

There is ongoing interest in efficient methods for separation and purification that are of low technology and mild enough to preserve the biological activity of proteins $[14,15]$. The aqueous two-phases system (ATPS) is an alternative to more intensive methods that has been used effectively in the early stages of some purification processes [16]. In some cases, ATPS can replace the traditional chromatographic systems which tend to be costly. Purification of enzymes by ATPS is highly effective, while still retaining a high 
Table 1

Levels of factors used in the $2^{4}$-experimental design selected for PG extraction by the PEG/potassium phosphate ATPS.

\begin{tabular}{llll}
\hline Coded values & \multicolumn{2}{l}{ Levels } \\
\cline { 2 - 4 } & Low $(-1)$ & Central $(0)$ & High $(+1)$ \\
\hline$M_{\text {PEG }}$ & 400 & 3350 & 8000 \\
$C_{\text {PEG }}$ & 12.5 & 15 & 17.5 \\
$C_{\text {PHOS }}$ & 15 & 20 & 25 \\
$\mathrm{pH}$ & 6.0 & 7.0 & 8.0 \\
\hline
\end{tabular}

level of activity [17-23]. An ATPS is formed by the incompatibility between aqueous solutions of two polymers, or a polymer and a salt at high ionic strength. The most widely used two polymer system is polyethylene glycol (PEG) and dextran. A polymeric and high salt ATPS is PEG and phosphate, sulphate or citrate, where the high salt concentration captures a large amount of water molecules from solution [24], which is the basis on which the system works.

ATPS offers many advantages including biocompatibility from the high water content in each phase; low-processing time; low-cost; low-energy consumption; reliability in scale-up, and simple technology $[22,23,25]$. In addition, proteins are protected from denaturation and loss of biological activity due to the high water content and low interfacial tension [24]. The partition of biomolecules in an ATPS is controlled by a set of parameters related to the molar mass and concentration of polymer, salt concentration, $\mathrm{pH}$ values, temperature, ionic strength and the structure of the molecule under analysis (e.g., its ionic charge, molar mass, hydrophobicity and conformational traits) [26-28].

Recently, the application of ATPS has been focused on enzyme extractions and purification including cellulases [22], collagenase [29], $\alpha$-galactosidase [30], laccase [31], lipase [32], pectinases [33-39], phytase [23], proteases [40] and tannase [15]. However, only a few studies on partitioning and purification of PG are addressed in literature [33-39]. In this context, the purpose of this study was to evaluate the partitioning and purification in a polyethylene glycol and phosphate salts ATPS of endo- and exo-PG produced by a high PG new producer strain of A. niger URM 5162 as described by Maciel et al. [1].

\section{Materials and methods}

\subsection{Reagents}

Chemicals used in this work were of analytical grade from Sigma-Aldrich (St. Louis, MO, USA).

\subsection{Polygalacturonases production in a fixed-bed reactor}

\subsubsection{Biomass immobilisation on natural support}

Immobilisation of $A$. niger URM 5162 biomass on orange peel was performed as previously described elsewhere [1].

\subsubsection{Submerged fermentation}

PG production was carried out in a fixed-bed reactor (FBR) using immobilised cells of the A. niger URM 5162 strain and a sample was removed after $72 \mathrm{~h}$. The FBR $(300 \mathrm{~mL})$ had a working volume of $260 \mathrm{~mL}$ and was run in continuous mode via a peristaltic pump [1]. The supernatant was the enzyme crude extract which was subjected to enzymatic analysis and extraction for PG by ATPS.

\subsection{Preparation of the ATPS}

ATPS systems were prepared with 3 molar masses of PEG $(400,3350$ and $8000 \mathrm{~g} / \mathrm{mol})$ and 3 phosphate salts concentrations (Table 1). Aqueous stock solutions of $40 \%(\mathrm{w} / \mathrm{w})$ phosphate were prepared by mixing appropriate amounts of potassium phosphate dibasic $\left(\mathrm{K}_{2} \mathrm{HPO}_{4}\right)$, potassium phosphate monobasic $\left(\mathrm{KH}_{2} \mathrm{PO}_{4}\right)$, sodium phosphate dibasic $\left(\mathrm{Na}_{2} \mathrm{HPO}_{4}\right)$ and sodium phosphate monobasic $\left(\mathrm{NaH}_{2} \mathrm{PO}_{4}\right)$ at 3 different $\mathrm{pH}$ values $(6.0,7.0$ and 8.0 ) at $25 \pm 1{ }^{\circ} \mathrm{C}$. The different concentrations of PEG and salt were added to graduated centrifuge tubes $(15 \mathrm{~mL})$ and the crude enzyme containing PG, representing $20 \%$ of the total system, was added to the tubes. Water was added to a final weight of $5 \mathrm{~g}$. The two phases were separated by settling for $60 \mathrm{~min}$ after vortex mixing for $1 \mathrm{~min}$. The phase volumes were determined, and the top and bottom phases were removed using pipettes. Approximately $1.5 \mathrm{~mL}$ were analysed for enzyme activity and protein content to determine the partition coefficient $(K)$, activity yield $(Y)$, purification factor $(\mathrm{PF})$ and selectivity $(S)$ of the PG.

\subsection{Analytical techniques}

Protein concentration was determined in triplicate at $595 \mathrm{~nm}$ [41] with bovine serum albumin as the standard. The endo-PG activity was measured viscosimetrically by mixing $5.5 \mathrm{~mL}$ of $1 \%$ $(\mathrm{p} / \mathrm{v})$ citric pectin in $0.025 \mathrm{M}$ acetate buffer at $\mathrm{pH} 5.0$ (supplemented with $1 \mathrm{mM}$ EDTA), with $250 \mu \mathrm{L}$ of the crude extract and incubated for $10 \mathrm{~min}$ at $50^{\circ} \mathrm{C}$ and then cooled in an ice bath. The viscosimetric unit $(U)$ was defined as the enzyme activity required to decrease the initial viscosity per minute by $50 \%$ [42]. The exoPG activity was determined by measuring the release of reducing groups from citric pectin using the 3,5-dinitrosalicylic acid assay [43]. The reaction mixture containing solution $\mathrm{A}(0.5 \mathrm{~mL} 0.5 \%$ citric pectin in $0.025 \mathrm{M}$ acetate buffer $)$ at $\mathrm{pH} 5.0$ and solution $\mathrm{B}(0.5 \mathrm{~mL}$ of enzymatic extract), was incubated at $50^{\circ} \mathrm{C}$ for $10 \mathrm{~min}$. One unit of enzymatic activity $(U)$ was defined as the required amount of enzyme needed to release $1 \mathrm{mmol}$ of galacturonic acid per minute. Enzymatic activities were expressed in units of activity as defined above per millilitre $(\mathrm{U} / \mathrm{mL})$.

\subsection{Experimental design and statistical analysis}

The effect of molar mass of PEG ( $\left.M_{\mathrm{PEG}}\right)$, PEG concentration $\left(C_{\mathrm{PEG}}\right)$, phosphate concentration $\left(C_{\mathrm{PHOS}}\right)$ and $\mathrm{pH}$, on $K, Y, \mathrm{PF}$ and $S$ was evaluated. $K, Y, P F$ and $S$ were determined on the findings obtained by a $2^{4}$ factorial design, plus central points, which was run in quadruplicate to allow estimation of the experimental error [44] (Table 1). The results were statistically analysed by analysis of variance (ANOVA) at a significance level $p \leq 0.05$. All the statistical and graphical analyses were carried out with Statistica 8.0 software (StatSoft Inc., Tulsa, OK, USA) [45].

\subsection{Determination of partition coefficient, activity yield, purification factor and selectivity}

$K$ was defined as the ratio of the volumetric enzyme activity in the top phase $(A t)$ over that in the bottom phase $(A b)$ :

$K=\frac{A t}{A b}$

PF was calculated as the ratio of the specific activity in the top phase over the specific activity in the cell extract before partition (Ai):

$\mathrm{PF}=\frac{A t / C t}{A i / C i}$

where, $\mathrm{Ct}$ and $\mathrm{Ci}$ are the total protein concentrations, expressed in $\mathrm{mg} / \mathrm{mL}$, in the top phase and initial extract, respectively. 
Table 2

Conditions and results of the $2^{4}$-experimental design for PG extraction by PEG/phosphate ATPS.

\begin{tabular}{|c|c|c|c|c|c|c|c|c|c|c|c|c|}
\hline & \multirow[t]{2}{*}{$M_{\mathrm{PEG}}(\mathrm{g} / \mathrm{mol})$} & \multirow[t]{2}{*}{$C_{\mathrm{PEG}}(\%)$} & \multirow[t]{2}{*}{$C_{\mathrm{PHOS}}(\%)$} & \multirow[t]{2}{*}{$\mathrm{pH}$} & \multicolumn{4}{|c|}{ Endo-PG } & \multicolumn{4}{|c|}{ Exo-PG } \\
\hline & & & & & $K$ & $Y$ & $\mathrm{PF}$ & $S$ & $K$ & $Y$ & $\mathrm{PF}$ & $S$ \\
\hline 1 & 400 & 12.5 & 15 & 6 & - & - & - & - & - & - & - & - \\
\hline 2 & 8000 & 12.5 & 15 & 6 & 0.94 & 76.60 & 3.87 & 0.81 & 1.69 & 17.49 & 0.88 & 1.45 \\
\hline 3 & 400 & 17.5 & 15 & 6 & 1.00 & 138.30 & 4.70 & 3.83 & 1.15 & 15.90 & 0.54 & 4.41 \\
\hline 4 & 8000 & 17.5 & 15 & 6 & 0.96 & 111.17 & 3.45 & 0.43 & 2.10 & 33.33 & 1.03 & 0.93 \\
\hline 5 & 400 & 12.5 & 25 & 6 & 1.06 & 76.06 & 4.43 & 1.51 & 1.92 & 16.57 & 0.96 & 2.75 \\
\hline 6 & 8000 & 12.5 & 25 & 6 & 1.23 & 74.04 & 8.18 & 24.68 & 2.40 & 17.97 & 1.98 & 48.07 \\
\hline 7 & 400 & 17.5 & 25 & 6 & 1.06 & 95.85 & 2.49 & 1.86 & 1.64 & 26.03 & 0.68 & 2.88 \\
\hline 8 & 8000 & 17.5 & 25 & 6 & 1.04 & 77.45 & 2.93 & 2.50 & 2.09 & 25.20 & 0.95 & 5.01 \\
\hline 9 & 400 & 12.5 & 15 & 8 & - & - & - & - & - & - & - & - \\
\hline 10 & 8000 & 12.5 & 15 & 8 & 1.00 & 86.17 & 1.05 & 0.24 & 2.06 & 22.11 & 0.27 & 0.50 \\
\hline 11 & 400 & 17.5 & 15 & 8 & 0.91 & 143.83 & 3.26 & 0.71 & 1.62 & 31.50 & 0.71 & 1.26 \\
\hline 12 & 8000 & 17.5 & 15 & 8 & 0.96 & 102.13 & 0.87 & 0.31 & 2.35 & 26.63 & 0.23 & 0.76 \\
\hline 13 & 400 & 12.5 & 25 & 8 & 0.87 & 60.00 & 3.31 & 0.54 & 2.12 & 13.78 & 0.76 & 1.32 \\
\hline 14 & 8000 & 12.5 & 25 & 8 & 0.83 & 52.66 & 1.95 & 0.32 & 2.00 & 21.50 & 0.80 & 0.77 \\
\hline 15 & 400 & 17.5 & 25 & 8 & 0.87 & 83.40 & 1.15 & 0.47 & 0.64 & 12.53 & 0.17 & 0.35 \\
\hline 16 & 8000 & 17.5 & 25 & 8 & 0.73 & 56.70 & 7.71 & 10.49 & 0.39 & 9.66 & 1.31 & 5.56 \\
\hline $17^{\mathrm{a}}$ & 3350 & 15.0 & 20 & 7 & 0.89 & 78.19 & 2.76 & 2.49 & 0.46 & 11.83 & 0.42 & 1.28 \\
\hline $18^{\mathrm{a}}$ & 3350 & 15.0 & 20 & 7 & 0.90 & 75.00 & 2.65 & 2.53 & 0.47 & 9.77 & 0.35 & 1.32 \\
\hline $19^{\mathrm{a}}$ & 3350 & 15.0 & 20 & 7 & 0.83 & 83.40 & 2.76 & 2.74 & 0.53 & 11.98 & 0.40 & 1.74 \\
\hline $20^{\mathrm{a}}$ & 3350 & 15.0 & 20 & 7 & 0.83 & 70.21 & 2.07 & 2.08 & 0.63 & 12.43 & 0.37 & 1.58 \\
\hline
\end{tabular}

- , not phase formation.

a Central point repetitions.

$Y$ was defined as the ratio of total activity in the top phase over that in initial extract expressed as a percentage:

$Y=\left(\frac{A t V t}{A i V i}\right) \times 100$

where, $V t$ and $V i$ are the volumes of the top phase and the initial extract, respectively.

The selectivity $(S)$ was defined as the ratio $K$ enzyme to the protein partition coefficient $(K p)$ :

$K p=\frac{C t}{C b}$

where, $C t$ and $C b$ are the total protein concentrations, expressed in $\mathrm{mg} / \mathrm{mL}$, in the top and bottom phase, respectively.

$S=\frac{K}{K p}$

\section{Results and discussion}

\subsection{Partition coefficient, activity yield and purification factor of endo-PG}

The highest enzymatic activities for endo-PG $(4.13 \mathrm{U} / \mathrm{mL})$ and exo-PG $(1.18 \mathrm{U} / \mathrm{mL})$ were detected after $72 \mathrm{~h}$ of fermentation. This time was the same used for the production and purification of PG from the fermentation crude [1].

The results for $K$ from endo-PG purification using the PEG/phosphate ATPS are presented in Table 2. Endo-PG partitioned preferentially in the top PEG rich phase $(K>1)$. These data corroborated those obtained by Lima et al. [34], that also described the endo-PG partitioning to the top phase $(K=1.35)$. Values of $K$ greater than a unity indicate effective partitioning to the top phase in the system [46]. Most pectinolytic enzymes preferentially partitioned into the PEG-rich top phase, particularly, when a PEG of low molar mass was used [36]. In contrast, Lima et al. [34] using PEG of high molar mass $(10.000 \mathrm{~g} / \mathrm{mol})$ the endo-PG was partitioned to the top phase. However, Antov et al. [38] used PEG of a low molar mass (PEG 4000/ammonium sulphate system) for endo-PG partitioning, and observed that the enzyme partitioned preferentially to the bottom salt-rich phase. Volume exclusion can occur in the case of PEG/salt systems consisting of high $M_{\mathrm{PEG}}$, due to the lack of molecular space for the enzyme [47,48]. High molar mass of PEG decreases the $K$ of the system [49]. In contrast, PEG of low molar mass increases the $K$ value and consequently the migration of enzyme to the PEG-rich phase.

In the present study, the effect of volume exclusion did not influence the partitioning of endo-PG. The enzyme partitioning to the top phase was observed when a high PEG molar mass $(8000 \mathrm{~g} / \mathrm{mol})$ was used. The possible cause could have been an electrostatic interaction between the endo-PG molecules, with a negatively charged surface lower than the $\mathrm{pH}$ used in the present study, and the positively charged PEG molecules. Kirsch et al. [40], Herculano et al. [22] and Neves et al. [23] also did not observe a volume exclusion effect on the partitioning of proteases, cellulases and phytase, respectively. However, the effect was observed by Rosso et al. [29] with collagenase from Penicillium aurantiogriseum, where an increase in concentration was observed in the bottom phase in almost all cases.

The low molecular weight $(35-85 \mathrm{kDa})$ of the endo-PG $[50,51]$ may also have influenced the partitioning for the PEG-rich top phase. Hence, in the top phase there was enough space for the accommodation of the enzyme when using PEG with high molecular weight $(8000 \mathrm{~g} / \mathrm{mol})$. Enzymes with high molar mass can be excluded due to the higher PEG molar masses [52]. Salting out can also be observed when the salt concentration in the bottom phase of the system is high and there is a migration of the enzyme to the PEG-rich phase [47]. This is not the case in the present study, since under the high value of $C_{\mathrm{PHOS}}$ the enzyme remained in the bottom phase.

The results of variations in $K(0.73-1.23), Y(52.66-143.83 \%)$, PF (0.87-8.18) and $S(0.24-24.68)$ of the endo-PG produced by $A$. niger URM 5162 are shown in Table 2. The optimal conditions were determined for the system with the following independent variables: $M_{\text {PEG }}$ of $8000(\mathrm{~g} / \mathrm{mol}), C_{\mathrm{PEG}}$ of $12.5 \%(\mathrm{w} / \mathrm{w})$, and $C_{\mathrm{PHOS}}$ of $25 \%$ $(\mathrm{w} / \mathrm{w})$ at $\mathrm{pH} 6.0$, which generated the results: $K=1.23, Y=74.04 \%$, $\mathrm{PF}=8.18$ and $S=24.68$ (Table 2, run 6).

$M_{\mathrm{PEG}}, C_{\mathrm{PEG}}$ and $C_{\mathrm{PHOS}}$, showed a positive effect on $K$ (Table 3 ). The positive effect means that the highest level of the 3 independent variables promoted the partitioning of the endo-PG to the top phase. In contrast, $\mathrm{pH}$ had a negative effect on $K$. The $\mathrm{pH}$ may have influenced the partitioning of the endo-PG to the top phase because the enzyme has an acidic isoelectric point [53] and a negatively charged surface under the pHs used in the present study. The 
Table 3

Effects calculated from the responses of results of the $2^{4}$-experimental design for the extraction of PG using PEG/phosphate ATPS.

\begin{tabular}{|c|c|c|c|c|c|c|c|c|}
\hline & \multicolumn{4}{|l|}{ Endo-PG } & \multicolumn{4}{|l|}{ Exo-PG } \\
\hline & K & $Y$ & $\mathrm{PF}$ & $S$ & $K$ & $Y$ & PF & $S$ \\
\hline (1) $M_{\mathrm{PEG}}$ & $12.35^{*}$ & 1.78 & $8.00^{*}$ & $32.63^{*}$ & $18.92^{*}$ & $12.18^{*}$ & $28.13^{*}$ & 65.84 \\
\hline (2) $C_{\mathrm{PEG}}$ & $10.29^{*}$ & $17.29^{*}$ & 2.83 & $32.61^{*}$ & -0.67 & $15.10^{*}$ & -0.22 & -63.10 \\
\hline (3) $C_{\mathrm{PHOS}}$ & $12.32^{*}$ & $-3.70^{*}$ & $11.23^{*}$ & $32.35^{*}$ & $7.01^{*}$ & -0.79 & $30.69^{*}$ & 62.12 \\
\hline (4) $\mathrm{pH}$ & $-7.13^{*}$ & -2.91 & $-8.06^{*}$ & $31.07^{*}$ & $-5.74^{*}$ & -3.13 & $-21.58^{*}$ & 60.67 \\
\hline $1 \times 2$ & $-14.28^{*}$ & $-12.06^{*}$ & -2.96 & $27.68^{*}$ & $-7.05^{*}$ & -8.43 & $-6.07^{*}$ & 57.45 \\
\hline $1 \times 3$ & $-12.66^{*}$ & $-6.69^{*}$ & $6.08^{*}$ & $26.27^{*}$ & $-15.40^{*}$ & $-9.89^{*}$ & $10.19^{*}$ & 56.36 \\
\hline $1 \times 4$ & -1.24 & -0.84 & -2.21 & $-20.21^{*}$ & $-3.56^{*}$ & -2.83 & $-13.29^{*}$ & -53.26 \\
\hline $2 \times 3$ & $-13.98^{*}$ & $-12.72^{*}$ & $-8.22^{*}$ & $-15.38^{*}$ & $-22.60^{*}$ & $-13.58^{*}$ & $-21.36^{*}$ & -51.41 \\
\hline $2 \times 4$ & -0.36 & -0.40 & $7.19^{*}$ & $-14.76^{*}$ & $-6.80^{*}$ & $-5.40^{*}$ & $9.52^{*}$ & -51.10 \\
\hline $3 \times 4$ & $-6.70^{*}$ & $-3.46^{*}$ & 2.19 & $-14.33^{*}$ & $-12.66^{*}$ & $-8.85^{*}$ & -2.25 & 50.90 \\
\hline $1 \times 2 \times 3$ & $10.41^{*}$ & $8.83^{*}$ & $9.88^{*}$ & $-13.37^{*}$ & $6.00^{*}$ & 3.01 & $11.69^{*}$ & -49.72 \\
\hline $1 \times 2 \times 4$ & 0.73 & -1.22 & $9.68^{*}$ & $-10.39^{*}$ & -2.17 & $-7.47^{*}$ & $11.48^{*}$ & -46.76 \\
\hline $1 \times 3 \times 4$ & -3.06 & -0.39 & $3.72^{*}$ & $-6.73^{*}$ & $-4.57^{*}$ & $4.65^{*}$ & $11.41^{*}$ & -38.66 \\
\hline $2 \times 3 \times 4$ & 1.58 & 0.78 & $8.99^{*}$ & $-6.67^{*}$ & $-8.94^{*}$ & $-7.21^{*}$ & $9.81^{*}$ & -36.14 \\
\hline
\end{tabular}

* Statistically significant values (at the $95 \%$ confidence level).

physical conditions discussed above make the endo-PG migrate to the top phase, which is positively charged and occurs through an electrostatic interaction between the endo-PG and PEG molecules. These results are in accordance by Cavalcanti et al. [54] and Azevedo et al. [55] that demonstrated negatively and positively charged proteins have a preference to the top and bottom phases, respectively.

The positive interaction between the variables $M_{\mathrm{PEG}}$ and $C_{\mathrm{PHOS}}$ promoted the highest values of PF. Lower pH showed negative effect in the statistical analysis of the response PF, where lower values provided a greater PF for endo-PG (Table 3). The highest value of PF (8.18) was obtained with $C_{\mathrm{PEG}}$ of $12.5 \%(\mathrm{w} / \mathrm{w})$ and $C_{\mathrm{PHOS}}$ of $25 \%$ (w/w) (Fig. 1).

The highest value of $Y(143.83 \%)$ was obtained using $400(\mathrm{~g} / \mathrm{mol})$ $M_{\mathrm{PEG}}, 17.5 \%(\mathrm{w} / \mathrm{w}) C_{\mathrm{PEG}}$ and $15 \%(\mathrm{w} / \mathrm{w}) C_{\mathrm{PHOS}}$ at $\mathrm{pH} 8.0$ (Table 2$)$. Higher levels of $C_{\mathrm{PEG}}$ and lower $C_{\mathrm{PHOS}}$ lead to an increase in $Y$ (Table 3). Comparable results were obtained by Lima et al. [34]. The authors used a PEG/potassium phosphate ATPS and obtained a highest PF of 16.28 and lowest $Y$ of $53.5 \%$ for endo-PG. In addition, Rosso et al. [29] used a PEG/phosphate ATPS for collagenase from $P$. aurantiogriseum URM 4622 and obtained higher values of PF (23.5)

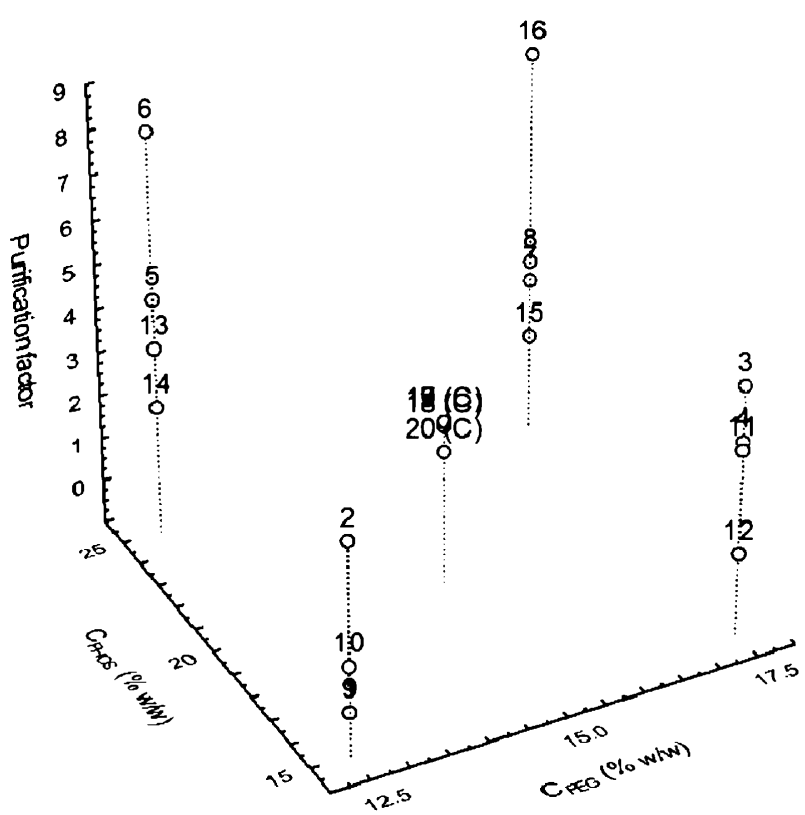

Fig. 1. Simultaneous effect of the response variables $C_{\mathrm{PEG}}(\%, \mathrm{w} / \mathrm{w})$ and $C_{\mathrm{PHOS}}(\%$, $\mathrm{w} / \mathrm{w}$ ) on the PF of endo-PG produced by the strain A. niger URM 5162 in ATPS. The experiments were performed according to the $2^{4}$-experimental design. and $Y(242 \%)$ obtained using 20\% (w/w) PEG 550 and $17.5 \%(\mathrm{w} / \mathrm{w})$ phosphate at $\mathrm{pH} 6.0$.

A $M_{\text {PEG }}$ of $8000(\mathrm{~g} / \mathrm{mol}), C_{\text {PEG }}$ of $12.5 \%(\mathrm{w} / \mathrm{w})$, and $C_{\text {PHOS }}$ of $25 \%$ $(\mathrm{w} / \mathrm{w})$ at $\mathrm{pH} 6.0$ was the most selective for effectively separating the endo-PG to the top phase and other enzymes to the bottom phase (Table 2, run 6). All variables and their interactions showed a significant effect on $S$ with $M_{\mathrm{PEG}}, C_{\mathrm{PEG}}, C_{\mathrm{PHOS}}$, and $\mathrm{pH}$ showing a positive effect on $S$. However, $C_{\mathrm{PHOS}}$ was the variable that had the higher effect on purification of endo-PG. Moreover, the positive interaction among $M_{\mathrm{PEG}}, C_{\mathrm{PEG}}$ and $C_{\mathrm{PHOS}}$ also affected positively $K$, $Y$ and $P F$, but had a negative effect on $S$ (Table 3 ). Cavalcanti et al. [56] and Kirsch et al. [40] observed that $C_{\text {PEG }}$ and $C_{\text {PHOS }}$ influenced $K, Y$ and PF. Moreover, $\mathrm{pH}$ was also considered to affect $K$ directly [57]. In the present study, $\mathrm{pH}$ had a significant negative effect on $K$ and PF for endo-PG.

\subsection{Partition coefficient, activity yield and purification factor of exo-PG}

For $K$, exo-PG preferentially partitioned to the top phase $(K>1)$ (Table 2). These data corroborated those obtained by Lima et al. [34], where the authors used PEG 400/phosphate with $\mathrm{NaCl}(K=5.35)$ and observed that the exo-PG partitioned to the top PEG-rich phase. As stated previously, most pectinolytic enzymes have a preference to the top rich-PEG phase, particularly, when a PEG of low molar mass is used [36]. Thus, Antov et al. [38] using a PEG 4000/ammonium sulphate system for exo-PG partition, observed that the enzyme preferentially partitioned to the bottom salt-rich phase. In the present study, $M_{\mathrm{PEG}}, C_{\mathrm{PHOS}}$ and $\mathrm{pH}$ were the significant independent variables: while $M_{\mathrm{PEG}}$ and $C_{\mathrm{PHOS}}$ showed a positive correlation and $\mathrm{pH}$ had a negative correlation with $K$ (Table 3 ). The effect of volume exclusion did not influence the partitioning of endo-PG, as the enzyme partitioned to the top phase when a high PEG molar mass $(8000 \mathrm{~g} / \mathrm{mol})$ was used. As discussed above, the $\mathrm{pH}$ may have influenced the partitioning of the exo-PG to the top phase due to the isoelectric point in the acidic region of the enzyme [58]. The effect of volume exclusion caused by high PEG molecular weight was not observed for endo-PG because of the low molar mass exo-PG (40-82 kDa) [51,59]. The salting out effect was not observed since in high $C_{\mathrm{PHOS}}$ concentration the enzyme remained in the bottom phase.

These results were confirmed as the optimal conditions for partitioning of exo-PG into the PEG-rich phase: $M_{\text {PEG }}$ of $8000(\mathrm{~g} / \mathrm{mol})$, $C_{\mathrm{PEG}}$ of $12.5 \%(\mathrm{w} / \mathrm{w})$, and $C_{\mathrm{PHOS}}$ of $25 \%(\mathrm{w} / \mathrm{w})$ at $\mathrm{pH} 6.0(K=2.40)$ (Table 2, run 6). Overall, results indicated variations in the $K$ (0.39-2.40), $Y$ (9.66-33.33\%), PF (0.23-1.98) and $S(0.35-48.07)$ of exo-PG produced by A. niger URM 5162 (Table 2). 


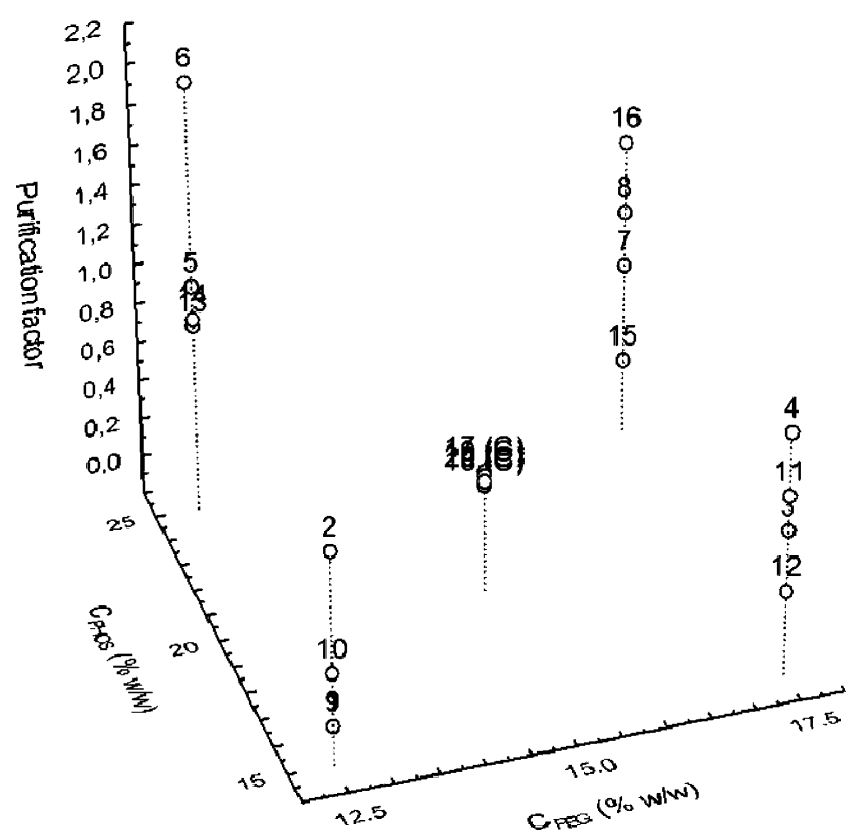

Fig. 2. Simultaneous effects of $C_{\mathrm{PEG}}(\%, \mathrm{w} / \mathrm{w})$ and $C_{\mathrm{PHOS}}(\%, \mathrm{w} / \mathrm{w})$ on $\mathrm{PF}$ of exo-PG from A. niger URM 5162 by ATPS. Experiments were performed according to the $2^{4}$-experimental design.

$M_{\mathrm{PEG}}$ and $C_{\mathrm{PEG}}$ were significantly positive in the statistical analysis of the response $Y$. The higher values of the $M_{\mathrm{PEG}}$ and $C_{\mathrm{PEG}}$ lead to greater $Y$ for exo-PG. In addition, the interaction between $C_{\mathrm{PEG}}$ and $C_{\mathrm{PHOS}}$ was negative, so that the increase in the $C_{\mathrm{PEG}}$ and decrease in the $C_{\mathrm{PHOS}}$, provided a greater $Y$ for exo-PG. As for endo-PG, the $C_{\mathrm{PHOS}}$ and $M_{\mathrm{PEG}}$ were significantly positive to $\mathrm{PF}$, whereas the $\mathrm{pH}$ was significantly negative to this response variable. The optimal conditions for PF (1.98) (Fig. 2) were a $M_{\text {PEG }}$ of 8000 (g/mol), $C_{\text {PEG }}$ of $12.5 \%(\mathrm{w} / \mathrm{w})$, and $C_{\mathrm{PHOS}}$ of $25 \%(\mathrm{w} / \mathrm{w})$ at $\mathrm{pH} 6.0$ (Table 2, run 6). Kirsch et al. [40] used a PEG/phosphate ATPS for proteases partition produced by Lentinus citrinus DPUA 1535 and showed that the proteases partitioned to the top phase. The authors obtained the best condition for proteases extraction with a $M_{\mathrm{PEG}}$ of 6000 $(\mathrm{g} / \mathrm{mol}), C_{\text {PEG }}$ of $17.5 \%(\mathrm{w} / \mathrm{w})$ and $C_{\mathrm{PHOS}}$ of $25 \%(\mathrm{w} / \mathrm{w})$. In addition, the values obtained for the response variables PF and $Y$ were 1.1 and $151 \%$, respectively. In order to evaluate the purification of $\alpha$ toxin from Clostridium perfringens type A, Cavalcanti et al. [56] used a PEG/phosphate ATPS and obtained the highest values for the PF (5.7) when using a $C_{\mathrm{PEG}}$ and $C_{\mathrm{PHOS}}$ of $17.5 \%$ and $15 \%$, respectively.

The conditions of $M_{\text {PEG }}$ of $8000(\mathrm{~g} / \mathrm{mol}), 12.5 \%$ of $C_{\text {PEG }}(\mathrm{w} / \mathrm{w})$, and $C_{\mathrm{PHOS}}$ of $25 \%(\mathrm{w} / \mathrm{w})$ at $\mathrm{pH} 6.0$ also were the most selective, allowing for separating the exo-PG in the top phase and other enzymes in the bottom phase (Table 2 , run 6 ). All variables and their interactions showed a significant effect on $S$ (Table 3 ). The $M_{\mathrm{PEG}}, C_{\mathrm{PHOS}}$, and $\mathrm{pH}$ showed a positive effect on $S$, where the increase of the values of these variables provides greater selectivity of the system. However, the $C_{\mathrm{PEG}}$ showed a negative effect in the response $S$, where lower values of this variable provided greater selectivity.

In addition, $M_{\mathrm{PEG}}$ was the independent variable which most influenced the response variables $K, Y, \mathrm{PF}$ and $S$ of exo-PG. This was also observed by Herculano et al. [22] who studied cellulases purification in ATPS. Lima et al. [34] observed that $M_{\text {PEG }}$ significantly influenced the $K$ of endo- and exo-PG. In the present study, the interaction between $C_{\mathrm{PEG}}$ and $C_{\mathrm{PHOS}}$ also influenced negatively the 3 variables response $K, Y, \mathrm{PF}$ and $S$ (Table 3 ).

Overall, the most suitable condition for the purification of endoand exo-PG produced by A. niger URM 5162 were $12.5 \%$ (w/w) PEG $8000,25 \%(\mathrm{w} / \mathrm{w}) C_{\mathrm{PHOS}}$, at $\mathrm{pH} 6.0$ which gave PFs of 8.18 and 1.98 and yields of $74.4 \%$ and $17.97 \%$ for endo-and exo-PG, respectively which were good results.

\section{Conclusion}

This paper shows the feasibility of using ATPS as a first step in the purification of PG from a fungal crude extract. Endo- and exo-PG were obtained in the top phase of the PEG/phosphate ATPS depending on what conditions were used. Very good results were obtained for an initial purification from a crude extract. The ATPS presented in this paper is a promising and low cost alternative for partial purification of PG produced by A. niger URM 5162.

\section{Acknowledgments}

M.H.C. Maciel thanks to Conselho Nacional de Desenvolvimento Científico e Tecnológico (CNPq, Brazil), Fundação de Amparo à Ciência e Tecnologia do Estado de Pernambuco (FACEPE/APQ0290-2.12/10), Financiadora de Estudos e Projetos (FINEP/ref. 2083/07) and Erasmus Mundus External Cooperation Window Lote 17. The authors thank the Laboratório de Tecnologia de Bioativos (LABTECBIO), Federal Rural University of Pernambuco (Recife, Brazil). M.H.C. Maciel, C.A. Ottoni, C. Santos and N. Lima also thank the FCT Strategic Project PEst-OE/EQB/LA0023/2013 and the Project "BioEnv - Biotechnology and Bioengineering for a sustainable world”, REF. NORTE-07-0124-FEDER-000048." Co-funded by the Programa Operacional Regional do Norte (ON.2-O Novo Norte), QREN, FEDER.

\section{References}

[1] M. Maciel, C. Ottoni, C. Santos, N. Lima, K. Moreira, C. Souza-Motta, Molecules 18 (2013) 1660-1671.

[2] M.A. Esawy, A.A. Gamal, Z. Kamel, A-M.S. Ismail, A.F. Abdel-Fattah, Carbohydr. Polym. 92 (2013) 1463-1469.

[3] A. Blandino, K. Dravillas, D. Cantero, S.S. Pandiella, C. Webb, Process Biochem. 37 (2001) 497-503.

[4] J.V.B. Souza, T.M. Silva, M.L.S. Maia, M.F.S. Teixeira, Process Biochem. 4 (2003) 455-458.

[5] I.G. Sandri, C.M.T. Lorenzoni, R.C. Fontana, M.M. Silveira, Food Sci. Technol. 51 (2013) 469-475.

[6] S. Kant, A. Vohra, R. Gupta, Protein Expr. Purif. 87 (2013) 11-16.

[7] S.O.S. Ling, R. Storms, Y. Zheng, M.R.M. Rodzi, N.M. Mahadi, R.M. Illias, A.M.A Murad, F.D.A. Bakar, Sci. World J. 2013 (2013) 1-8.

[8] N.P. Patil, K.P. Patil, B.L. Chaudhari, S.B. Chincholkar, Indian J. Microbiol. 52 (2012) 240-246.

[9] A.O.B. Ribon, J.B. Ribeiro, D.B. Gonçalves, M.V. Queiroz, E.F. Araújo, Genet. Mol. Biol. 32 (2009) 129-132.

[10] H.A. Murad, H.H. Azzaz, Res. J. Microbiol. 6 (2011) 246-269.

[11] R.S. Jayani, S. Saxena, R. Gupta, Process Biochem. 40 (2005) 2931-2944.

[12] H. Abbasi, H. Shafighzadeh, A. Rahimi, Iran J. Biotechnol. 9 (2011) 50-55.

[13] R.C. Fontana, M.M. Silveira, Braz. J. Chem. Eng. 29 (2012) 683-690.

[14] D. Spelzini, B. Farruggia, G. Picó, Process Biochem. 46 (2011) 801-805.

[15] L.V. Rodríguez-Durán, D. Spelzini, V. Boeris, C.N. Aguilar, G.A. Picó, Colloids Surf. B: Biointerfaces 101 (2013) 392-397.

[16] P.M.D. Jamarillo, H.A.R. Gomes, F.G. Siqueira, M. Homem-de-Mello, E.X. Ferreira Filho, P.O. Magalhães, Purif. Technol. 120 (September) (2013) 452-457.

[17] Z.D.V.L. Mayerhoff, I.C. Roberto, T.T. Franco, Biochem. Eng. J. 18 (2004) 217-223.

[18] S. Gautam, L. Simon, Biochem. Eng. J. 30 (2006) 104-108.

[19] S. Yang, Z. Huang, Z. Jiang, L. Li, Process Biochem. 43 (2008) 56-61.

[20] R. Kammoun, H. Chouayekh, H. Abid, B. Naili, S. Bejar, Biochem. Eng. J. 46 (2009) 306-312.

[21] Y. Zhang, J. Liu, J. Chromatogr. B 878 (2010) 909-912.

[22] P.N. Herculano, T.S. Porto, M.H.C. Maciel, K.A. Moreira, C.M. Souza-Motta, A.L.F Porto, Fluid Phase Equilib. 335 (2012) 8-13.

[23] M.L.C. Neves, T.S. Porto, C.M. Souza-Motta, M.R. Spier, C.R. Soccol, K.A. Moreira, A.L.F. Porto, Fluid Phase Equilib. 318 (2012) 34-39.

[24] J.A. Asenjo, B.A. Andrews, J. Chromatogr. A 1218 (2011) 8826-8835.

[25] K. Ratanapongleka, J. Int. Chem. Eng. Appl. 1 (2010), ISSN 2010-0221.

[26] M.G. Antov, D.M. Pericin, Enzyme Microb. Technol. 28 (2001) 467-472.

[27] P.A.J. Rosa, I.F. Ferreira, A.M. Azevedo, M.R. Aires-Barros, J. Chromatogr. A 1217 (2010) 2296-2305.

[28] J.C-W. Lan, C-Y. Yeh, C-C. Wang, Y-H. Yang, H-S. Wu, J. Biosci. Bioeng. 116 (2013) $499-505$.

[29] B.U. Rosso, C.A. Lima, T.S. Porto, C.O. Nascimento, A.P. Junior, A. Converti, M.G. Carneiro-da-Cunha, A.L.F. Porto, Fluid Phase Equilib. 335 (2012) 20-25. 
[30] K. Naganagouda, V.H. Mulimani, Process Biochem. 43 (2008) 1293-1299.

[31] S.C. Silvério, O. Rodríguez, A.P.M. Tavares, J.A. Teixeira, E.A. Macedo, J. Mol. Catal. B: Enzym. 87 (2013) 37-43.

[32] S.P.M. Ventura, R.L.F. Barros, J.M.P. Barbosa, C.M.F. Soares, A.S. Lima, J.A.P. Coutinho, Green Chem. 14 (2012) 734-740.

[33] Y.-T. Wu, M. Pereira, A. Venâncio, J. Teixeira, J. Chromatogr. A 929 (2001) 23-29.

[34] A.S. Lima, R.M. Alegre, A.J.A. Meirelles, Carbohydr. Polym. 50 (2002) 63-68.

[35] M. Pereira, A. You-Ting Wu, J. Venâncio, Teixeira, Biochem. Eng. J. 15 (2003) $131-138$

[36] M.G. Antov, G.M. Pericin, G.R. Dimić, J. Biotechnol. 91 (2001) 83-87.

[37] M.G. Antov, Carbohydr. Polym. 56 (2004) 295-300.

[38] M.G. Antov, D.M. Pericin, S.N. Pejin, J. Serb. Chem. Soc. 69 (2004) 299-307.

[39] M.G. Antov, R. Omorjan, Bioprocess Biosyst. Eng. 32 (2009) 235-240.

[40] L.S. Kirsch, A.C.S. Pinto, M.F.S. Teixeira, T.S. Porto, A.L.F. Porto, Quim. Nova 35 (2012) 1912-1915.

[41] M.M. Bradford, Anal. Biochem. 72 (1976) 248-254

[42] B.R. Tuttobello, P.J. Mill, Biochem. J. 79 (1961) 51-57.

[43] J.B. Sumner, G.F. Somers, Laboratory Experiments in Biological Chemistry, New York, Academic Press, 1994

[44] B. Barros-Neto, I.C. Scarminio, R.E. Bruns, Como fazer experimentos: pesquisa e desenvolvimento na ciência e na indústria, 2nd ed., Editora da Universidade de Campinas, Campinas, SP, Brazil, 2002.

[45] Statsoft Inc., Statistica (Data Analysis Software Systems) Version 8.0, 2008.

[46] P.G. Mazzola, A.M. Lopes, F.A. Hasmann, A.F. Jozala, T.C.V. Penna, P.O. Magalhaes, C.O. Rangel-Yagui, A. Pessoa Jr., J. Chem. Technol. Biotechnol. 83 (2008) $143-157$.
[47] T.S. Porto, G.M. Medeiros e Silva, C.S. Porto, M.T.H. Cavalcanti, B.B. Neto, J.L. Lima-Filho, A. Converti, A.L.F. Porto, A. Pessoa Jr., Chem. Eng. Process 47 (2008) $716-721$.

[48] T.S. Porto, P.P. Marques, C.S. Porto, K.A. Moreira, J.L. Lima-Filho, A. Converti, A. Pessoa Jr., A.L.F. Porto, Appl. Biochem. Biotechnol. 160 (2010) 1057-1064.

[49] A.P.B. Rabelo, E.B. Tambourgi, A. Pessoa Jr., J. Chromatogr. B 807 (2004) 61-68.

[50] R.D. Cooke, C.E. Ferber, L. Kanagasabapathy, Biochim. Biophys. Acta 452 (1976) 440-451.

[51] M.L. Buga, S. Ibrahim, A.J. Nok, Afr. J. Biotechnol. 9 (2010) 8934-8943.

[52] G.G.G. Oliveira, D.P. Silva, I.C. Roberto, M. Vitolo, A. Pessoa-Júnior, Braz. J. Pharm. Sci. 37 (2010) 177-187.

[53] L. Parenicová, H.C.M. Kester, J.A.E. Benen, J. Visser, FEBS Lett. 467 (2000) 333-336.

[54] M.T.H. Cavalcanti, T.S. Porto, B. Barros Neto, J.L. Lima Filho, A.L.F. Porto, A. Pessoa Jr., J. Chromatogr. B 833 (2006) 135-140.

[55] A.M. Azevedo, A.G. Gomes, P.A.J. Rosa, I.F. Ferreira, A.M.M.O. Pisco, M.R. AiresBarros, Sep. Purif. Technol. 65 (2009) 14-21.

[56] M.T.H. Cavalcanti, T.S. Porto, B.B. Neto, J.L. Lima-Filho, A.L.F. Porto, A. Pessoa Jr J. Chem. Technol. Biotechnol. 83 (2008) 158-162.

[57] D. Voet, J.G. Voet, C.W. Pratt, Fundamentos de Bioquímica, 1st ed., Editora Artes Medicas Sul, Porto Alegre, RS, 2000, 931 pp.

[58] H.C. Kester, J. Visser, Biotechnol. Appl. Biochem. 12 (1990) 150-160.

[59] T. Sakamoto, E. Bonnin, B. Quemener, J.F. Thibault, Biochim. Biophys. Acta 1572 (2002) 10-18. 